\title{
Meningkatkan Hasil Belajar PJOK Materi Operan Dalam Permainan Sebak Bola Dengan Tekhnik Give And Go Pada Siswa Kelas VI SDN Esot Kecamatan Pringgarata Tahun Pelajaran 2019/2020
}

\author{
Muslimin \\ Kepala Sekolah SDN Esot Kec. Pringgarata Kab. Lombok Tengah
}

\begin{abstract}
Abstrak. Penelitian ini adalah penelitian tindakan kelas dengan judul Meningkatkan Hasil Belajar PJOK Materi operan dalam permainan sebak bola dengan tekhnik give and go pada siswa Kelas VI SDN Esot Kecamatan Pringgarata Tahun Pelajaran 2019/2020. Adapun tujuan daripenelitian ini adalah untuk Meningkatkan Hasil Belajar PJOK Materi operan dalam permainan sebak bola dengan tekhnik give and go pada siswa Kelas VI SDN Esot Kecamatan Pringgarata Tahun Pelajaran 2019 /2020. Subyek penelitian adalah siswa kelas VI dengan jumlah siswa 28 orang terdiri dari siswa laki-laki 15 orang dan perempuan 13 orang. Penelitian ini direncanakan dalam beberapa siklus.. Masing-masing siklus terdiri dari empat tahapan kegiatan yaitu perencanaan tindakan, pelaksanaan tindakan, observasi dan evaluasi, serta refleksi.( arikunto ;2013; 137) Sebelum diberikan perlakuakn Berdasarkan hasil ulangan PJOK pada materi sepak bola di kelas VI SDN Esot Kecamatan Pringgarata yang diikuti 28 peserta, yang tuntas belajar hanya 9 orang siswa atau sebesar $32 \%$,dan sebanyak 19 siswa belum tuntas belajar atau sebesar $68 \%$, dan KKM yang ditetapkan untuk mata pelajaran PJOK di SDN Esot Kecamatan Pringgarata untuk tahun pelajaran 2019/ 2020 adalah yaitu 70 dan ketuntasan klasikal sebesar $\geq 80 \%$ Rendahnya hasil belajar siswa ternyata disebabkan karena penggunaan tekhnik yang kurang tepat, menendang dan mengumpan dan mengoper bola masih kurang dalam mengajarkan cara bermain bola, kemudian metode yang digunakan kurang tepat atau tidak sesuai dengan materi yang akan diajarkan yaitu metode konvensional disamping itu juga lapangan yang tersedia di sekolah kurang mendukung karena memiliki halaman yang sempit. Setelah diberikan perlakuan berdasarkan anlisis hasil dari kedua siklus tersebut diatas terjadi peningkatan hasil belajar yang signifikan dari siklus I menuju siklus II , nilai rata - rata diperoleh pada siklus I sebesar 68,42 kemudian meningkat pada siklus II nilai rata - rata diperoleh sebesar 82,89 terjadi peningkatan sebesar 14,47 poin , kemudian jumlah siswa yang tuntas pada siklus I sebanyak 12 siswa dengan persentase sebesar $42 \%$ dan pada siklus II jumlah siswa yang tuntas sebanyak 26 siswa dengan persentase sebesar $93 \%$ terjadi peningkatan sebesar 51 poin, begitu juga dengan ketuntasan klasikal yang dipatok sebesar $\geq 80 \%$ juga sudah tercapai maka dengan demikian semua indikator yang dipersyaratkan sudah tercapai, maka penelitian ini dihentikan sampai pada siklus II. Dengan demikian dapat ditarik kesimpulan bahwa dengan menggunakan tekhnik operan dalam permainan sepak bola dengan tekhnik give and go dapat meningkatkan hasil belajar siswa kelas VI di SDN Esot Kecamatan Pringgarata Tahun pelajaran 2019/2020.
\end{abstract}

Kata kunci: Hasil Belajar, Tekhnik Give And Go

\section{PENDAHULUAN}

Sepakbola adalah salah satu jenis olah raga yang sangat digemari orang seluruh dunia. Olah raga ini sangat universal. Selain digemari orang laki-laki olah raga ini juga digemari para perempuan tidak hanya tua muda bahkan anak-anak Sejak tahun 1990 an olah raga ini mulai digunakan untuk para wanita meskipun sebelumnya olah raga ini hanya diperuntukkan bagi kaum pria.

Olah raga ini melibatkan 11 orang dalam satu teamnya. Untuk menjadi pemenang dalam suatu pertandingan harus melawan satu team lainnya. Para pemain sepak bola memperebutkan sebuah bola untuk dimasukkan ke dalam gawang yang dijaga seorang penjaga gawang (goal 
keeper).Olah raga ini menjadi sangat menarik karena selain hanya memperebutkan sebuah bola di lapangan dengan menggunakan kaki tetaspi juga terlihat gaya-gaya permainannya dalam memperebutkan bola untuk memasukkan bola ke dalam gawang lawan. Oleh karena olah raga ini melibatkan banyak orang tentunya kerjasama team yang baik sangat dibutuhkan selain teknik bermain yang baik.

Hanya para atlet sepak bola mania Negara yang sukses membina karier di bidang olah raga ini. Tentunya diperlukan usaha dan latihan yang keras untuk menjadi atlet sepak bola yang handal dan professional di dalam permainan sepak bola, baik di kampung, halaman rumah, sekolah, lapangan kecil atau di stadion yang megah.

Olah raga ini juga dilakukan anak kecil, anak-anak, remaja , pemuda , orang dewasa, pria bahkan wanita. Sepakbola sungguh populer di mata masyarakat, dari pelosok desa hingga kota besar di seluruh dunia.

Sepak bola merupakan olah raga yang simple, sederhana dan murah. Bahkan hampir tidak memerlukan biaya. Namun bila pertandingan yang profesional, olah raga ini biayanya bisa terbesar dari aneka cabang olah raga lainnya. Untuk mengelola dan menghidupkan sebuah klub sepak bola bisa memakan biaya milyaran rupiah. Di satu pihak sepak bola dikatakan hampir tidak memerlukan biaya, karena alat dan sarana yang dibutuhkan hanya satu benda bulat dan tanah lapang. Benda bulat yang disebut bola itu bisa bola yang mahal, (bola karet), bola plastic, jeruk bali (keprok) atau jerami, kertas, serabut kelapa, yang pengelola harus mengadakan studi banding, harus tanggap akan anak asuhnya, mau belajar dari pengalaman pahit, sekaligus berusaha membuktikan pengelolaan yang lebih professional.

Faktor tersebut yang menarik untuk dikaji bersama penelitian ini adalah tekhnik dalam permainan bola yaitu bagaimana melulakan dive header , bagaimana cara melakukan jumpn header dan sebagainya , akan memudahkan pemain tersebut dalam rangka membawa bola (menggiring bola) mengoper bola hingga ke hadapan gawang lawan.

Berdasarkan hasil ulangan PJOK pada materi sepak bola di kelas VI SDN Esot Kecamatan Pringgarata yang diikuti 28 peserta, yang tuntas belajar hanya 9 orang siswa atau sebesar $32 \%$ ,dan sebanyak 19 siswa belum tuntas belajar atau sebesar $68 \%$, dan KKM yang ditetapkan untuk mata pelajaran PJOK di SDN Esot Kecamatan Pringgarata untuk tahun pelajaran 2019/2020 adalah yaitu 70 dan ketuntasan klasikal sebesar $\geq 80$ $\%$

Rendahnya hasil belajar siswa ternyata disebabkan karena penggunaan tekhnik yang kurang tepat, menendang dan mengumpan dan mengoper bola masih kurang dalam mengajarkan cara bermain bola, kemudian metode yang digunakan kurang tepat atau tidak sesuai dengan materi yang akan diajarkan yaitu metode konvensional disamping itu juga lapangan yang tersedia di sekolah kurang mendukung karena memiliki halaman yang sempit.

Maka Peneliti mencoba untuk menawarkan alternatif pemecahan masalah untuk meningkatkan hasil belajar pada mata pelajaran PJOK dalam melatih cara mengoper bola dalam bermain sepak bola yaitu dengan tekhnik operan give and go, sehingga peneliti mengambil judul" Meningkatkan Hasil Belajar PJOK Materi operan dalam permainan sebak bola dengan tekhnik give and go pada siswa Kelas VI SDN Esot Kecamatan Pringgarata Tahun Pelajaran 2019 /2020.

\section{Rumusan Masalah}

Berdasarkan latar belakang diatas maka dirumuskan suatu masalah sebagai berikut:" Bagimanakah Meningkatkan Hasil Belajar PJOK Materi operan dalam permainan sebak bola dengan tekhnik give and go pada siswa Kelas VI SDN Esot Kecamatan Pringgarata Tahun Pelajaran 2019/2020.

\section{Tujuan Penelitian}

Sesuai dengan permasalahan diatas, penelitian ini bertujuan untuk: 
Meningkatkan Hasil Belajar PJOK Materi Operan dalam permainan sebak bola dengan tekhnik give and go pada siswa Kelas VI SDN Esot Kecamatan Pringgarata Tahun Pelajaran 2019 /2020.

\section{Manfaat Penelitian}

Penelitian ini diharapkan dapat memberi manfaat bagi siswa, guru dan sekolah, Memudahkan siswa untuk memahami materi yang sedang dipelajari sihingga hasil belajar siswa meningkat

\section{KAJIAN PUSTAKA \\ Sejarah Singkat Sepak Bola}

Permainan sepak bola berasal dari Inggris. Pada tanggal 26 Oktober 1963 terdapat organisasi yang menyusun peraturan permainan. Yaitu The Foodball Association . Federasi sepak bola dunia yaitu Federaion Internasional the Foodball Association (FIFA) dibentuk pada tanggal 21 September 1904, diketuai oleh Guirin.

Bangsa Indonesia mengenal permainan sepak bola dari bangsa Belanda. Pada tanggal 19 april 1930 di Yogyakarta, dibentuk Persatuan Sepakbola seluruh Indonesia (PSSI) yang diketuai oleh $\mathrm{Mr}$ Soeratin Sosro Soegondo.

Permainan sepak bola termasuk permainan bola besar. Sepak bola dimainkan di lapangan rumput oleh dua regu atau dua kesebelasan yang saling berhadapan. Tujuan permainan sepak bola adalah memasukkan bola ke gawang lawan sebanyak-banyaknya dan mempertahankan daerah sendiri dari serangan lawan. Karakteristik permainan adalah memainkan bola dengan menggunakan kaki ataupun dengan seluruh anggota tubuh kecuali oleh lengan.

Hakekat permainan sepak bola adalah mempertahankan dan penyerangan (Pend. Jasmani SD kelas VI , Slamet, 26) maka untuk kelincahan dan kecepatan yang diprediksikan berpengaruh terhadap kemampuan menggiring bola, berpatokan pada hakekat permainan yang menitik beratkan pada pertahanan dan nilai tersendiri bagi penonton) jika mereka memahami betul akan peraturan permainan sepak bola, sikap yang dilarang untuk dilakukan dalam permainawn, tentu mereka akan terlihat lincah, cepat dan atraktif.

Penelitian ini juga berlandaskan pada penerobosan strategi pertahanan lawan, tekhnik mengoper bola, teknik menghadang lawan, teknik mengendalikan lawan, teknik merebut bola dan sebagainya. Dengan dasar kemampuan pemahaman teknik-teknik tersebut, tentu mendukung kualitas pemain dalam melakukan unsur kelincahan dan kecepatan. Baik pada saat sendirian, atau bersama kawan bermain.

\section{Teknik Dasar Permainan Sepak Bola}

Ada beberapa teknik dasar dalam permainan sepak bola yang harus dikuasai oleh pemain , antara lain keterampilan heading, keterampilan mengoper , keterampilan menembak, Menjaga gawang, serangan berkelompok , pertahanan kelompok, menendang, menggiring, mengontrol , menyundul dan menghentikan bola.

\section{Teknik Gerakan dengan Bola Pola Penyerangan}

Pemain yang menguasai bola, sebelum bola tersbut dioperkan kepada temannya akan melakukan gerakan dengan bola, baik itu berupa " berlari dengan bola" aau gerakan menggiring bola. Memang terdapat sedikit perbedaan antara " berlari dengan bola" dan menggiring bola. Berlari dengan bola selalu dalam jangkauan. Langkah konstan dan tidak terlalu sering menyentuh bola. Sedangkan menggiring bola adalah mengubah arah dan kecepatan bola dengan sentuhan-sentuhan kaki yang cepat.

\section{Wall Pass atau Operan Satu-Dua}

Wall Pass atau operan satu-dua memang merupakan gerak yang sangat sederhana dari dua orang pemain. Pemain A mengoper bola pada $b$, kemudian lari ke posisi baru. Pemain B tanpa menahan bola mengoper kembali kepada A yang menerima bola tersebut pada posisi baru. Walaupun sederhanam namun diperlukan latihan yang tekun dan sungguh-sungguh dari pemain. Diperlukan kecerdikan dari pemberi bola pertama untuk mencari “" 
lobang" kemana dia bisa berlari untuk menerima operan keduaaa.

Bagi penerima operan pertama, diperlukan kemahiran untuk memperhitungkan saat dalam melakukan operan kedua yang akuran, sehingga pemberi operan pertama dapat " bertemu" bola pada posisi baru saat yang tepat. Perlu diingat bahwa pemain yang melakukan operan yang pertama kemudian " pelari" yang harus mencari posisi baru yang kosong untuk menerima operan kedua dari temannya. Pelari inilah yang menentukan kemana operan kedua harus dilakukan.

\section{Lemparan ke Dalam}

Jika dilakukan secara baik, berencana dan dilatih dengan sunguhsungguh maka lemparan ke dalam dapat menjadi awal dari serangan yang berbahaya. Terutama sekali jika lemparan ke dalam ini terjadi di daerah pertahaan lawan.

\section{Tendangan Penjuru}

Keberhasilan tendangan sudut ke kotak penalty bergantung kepada dua hal yaitu (a) Keterampilan pemain penyerang dalam menyundul bola ke gawang lawan, (b) Kemampuan pihak bertahan untuk menyapu bola-bla tinggi didaerah penalty, termasuk kemahiran penjaga gawang dalam memotong dan menangkap bola-bola tinggi di kotak penalty.

\section{Teknik Gerakan dengan Bola Pola Pertahanan}

Dalam permainan sepak bola dikenal tiga bariasan pemain yaitu (1) Barisan Penyerang, (2) Barisan Pemain lapangan tengah (3) barisan pertahanan (pemain belakang). Pemain belakang atau barisan pertahanan ini mempunyai " tugas utama" , untuk mempertahankan dan melindungi daerah berbahaya atau gawangnya dari serangan lawan. Dalam menjalankan tugas utama ini, terdapat caracara, tugas, pola teknik, atau strategi tertentu yang perlu dipahami.

Hal ini diperlukan agar dalam menjalankan kegiatan sebagai pemain bertahan, pertahanan itu terlaksana dengan terkoordinir dan terpola serta merupakan gerakan bersama bukan tindakan sendirisendiri yang lepas satu sama lain.

\section{Latihan Bermain Dengan Teknik Sederhana}

Latihan bermain sepak bola mempunyai berbagai tujuan khusus, antara lain dapat (1) meningkatkan penguasaan keterampilan teknis dalam situasi bermain (2) melatih dan menerapkan teknik tertentu, (3) melatih kerja sama yang baik bagian atau unit tertentu, maupun tim secara keseluruhan dan (4) meningkatkan kualitas fisik.

$\begin{array}{cccc} & \text { Teknik } & \text { dasar yang } & \text { telah } \\ \text { dipelajari } & \text { seperti } & \text { menggiring } & \text { bola, }\end{array}$ mengoper bola, cara menerima bola, menembak dan sebagainya diterapkan lagi dalam bentuk latihan bermain. Dalam hal ini kita dihadapkan dengan situasi permainan yang sebenarnya. Artinya dalam mengolah bola akan senantiasa berhadapan dengan lawan inilah yang menjadi tujuan latihan. Apabila siswa telah mampu menguasai situasi tersebut, maka dapat dikatakan telah menguasai teknik sepak bola sebenarnya. Maksudnya siswa tidak saja menguasai teknik sepak bola konteks latihan teknik tetapi telah menguasai teknik sepak bola dalam situasi permainan atau pertandingan sesungguhnya.

Selanjutnya berbagai strategi teknik bermain, gerakan tertentu, tidak akan dapat dikuasai tanpa penerapan di lapangan, terutama dalam situasi permainan. Hal tersbut dilatih dalam bentuk-bentuk latihan bermain dnegan tugas-tugas yang ditentukan, sesuai dngan aspek-aspek seperti yang dikemukakan di atas. Bersamaan dengan melatih unsur-unsur tersebut terbina pula kerjasama antara pemain dalam unit-unit tertentu menurut tugas masing-masing.

Dengan latihan bermain siswa dilatih penguasaan segi teknik, menerapkan teknik, strategi dan gerakan tertentu serta melatih kerjasama. Siswa juga dalam waktu yang bersamaan memelihara bahkan dengan penekanan khusus dapat meningkatkan 
kondisi fisik yang sesuai degan tuntutan permainan sepak bola.

\section{Tekhnik operan give and go}

Cara melakukan operan Give and go.

Numbers -up situation yang paling dasar adalah situasi dua lawan satu. Artinya dua penyerang melawan satu pemain bertahan, nah dalam situation seperti itu taktik utama yang dapat dilakukan adalah operan give and go. Untuk melakukan operan ini cukup sederhana, misalnya kamu dalah penyerang petama yang menguasai bola giringlah bola dan arahkan pemain bertahan kearahmu, kemudian operlah bola kerah rekan seregumu yang terdekat ( penyerang kedua) selanjutnya berlarilah kebelakang pemain bertahan untuk menerima operan balik. Jika kamu menjadi penyerang pertama dalam situasi dua lawan satu, kamu bertanggung jawab untuk memulai gerakan.

Langkah - langkah sebagai berikut: (1) Mengahadapi lawan, lakukan dribel dihadapan pemain setelah kamu ketahui adanya number -up situation, tindakan akan memaksa lawan segera membuat keputusan yaitu mundul atau merebut bola, (2) Mengarahkan lawan , tariklah lawan kearahmu, (3) Memgoperkan bola. Lepaskan operanmu ketika pemain bertahan merapat men -tackle.Gunakan bagian samping luar kura - kura kakimu untuk mengeper bola ke rekan seregumu, (4) Berlari dengan cepat keruang terbuka. Setelah mengoper bola, berlarilah keruang di belakang pemain bertahan, (6) Menerima operan balik.Terimalah operan dari temanmu.

Jika kamu menjadi penyerang kedua dalam situasi dua lawan satu, langkah yang harus kamu lakukan adalah sebagai berikut : (1) Bergerak keposisi dekat bola. Jika kamu mengetahui ada kesempatan untuk melakukan operan give and go tempatkan dirimu disamping pemain bertahan. Jaraknya sekitar 2,5 - 3, $6 \mathrm{~m}$ dengan sudut kira - kira 45 derajat dari penyerang pertama, (2) Menempati posisi sebagai dinding gunakan posisi berdiri yang terbuka dengan memutar tubuh kearah penyerang pertama. Kaki mendahului bertindak sebagai dinding untuk mempertahankan bola, (3) Mengoperkan bola dengan satu sentuhan keruang terbuka arahkan kembali operan dari penryerang pertama keruang terbuka di belakang pemain betahan, (4) Dukunglah operanmu berlarilah kedepan untuk mendukung teman seregumu setelah mengoper bola, situasi give and go lainnya dapat segera dilakukan.

\section{METODE PENELITIAN}

\section{Setting Penelitian}

Jenis penelitian yang dilakukan oleh peneliti adalah penelitian tindakan kelas (Classroom Action Research). "Penelitian Tindakan Kelas (PTK) adalah suatu pencermatan terhadap kegiatan belajar berupa sebuah tindakan yang sengaja dimunculkan dan terjadi dalam sebuah kelas secara bersama".(Arikunti;2009; 3) Adapun langkah-langkah dalam setiap siklus adalah sebagai berikut: Perencanaan tindakan pelaksanaan tindakan, mengobservasi, mengevaluasi dan refleksi

\section{Tempat dan Waktu Penelitian}

Penelitian ini bertempat di SDN Esot Kecamatan Pringgarata tahun pelajaran $2019 / 2020$ yang beralamat di Esot Kecamatan Pringgarata kabupaten Lombok Tengah. Penelitian ini dilaksanakan pada bulan Juli sampai dengan September semester ganjil tahun pelajaran 2019 /2020

\section{Subyek penelitian}

Subyek penelitian adalah siswa kelas VI dengan jumlah siswa 28 orang terdiri dari siswa laki-laki 15 orang dan perempuan 13 orang mereka berasal dari sekitar lingkungan sekolah SDN Esot yang berada di pedesaan.

\section{Prosedur penelitian}

Penelitian ini direncanakan dalam beberapa siklus.. Masing-masing siklus terdiri dari empat tahapan kegiatan yaitu perencanaan tindakan, pelaksanaan tindakan, observasi dan evaluasi, serta refleksi.( arikunto ;2013; 137) Adapun model dan penjelasan untuk masing-masing tahap adalah sebagai berikut. 


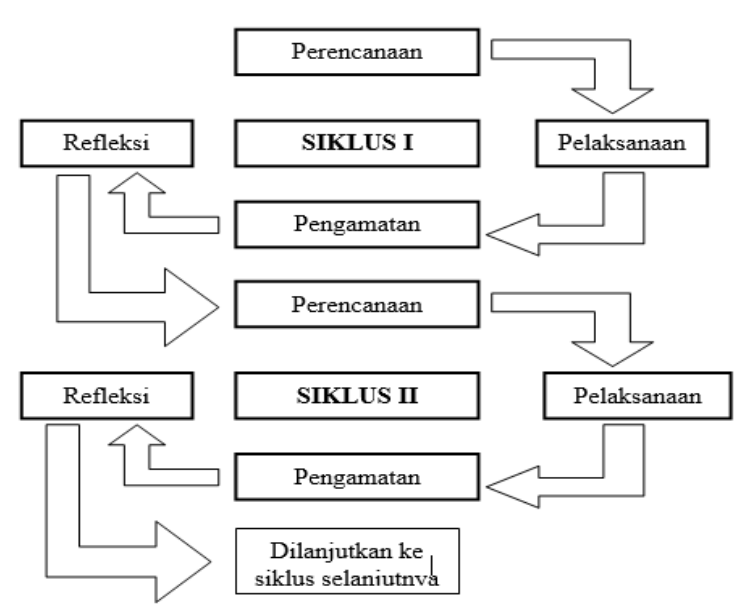

Gambar 1.2 : Siklus Penelitian Tidakan Instrumen Penelitian

Instrument yang digunakan dalam penelitian ini terdiri dari: (1) Rencana Pembelajaran (RP), (2) Tes praktek, (3) Lembar tes tulis untuk mengetahui ketuntasan belajar siswa.

\section{Metode Pengumpulan Data}

Data-data yang diperlukan dalam penelitian ini diperoleh melalui observasi pengolahan tes hasil belajar .

\section{Teknik Analisa Data}

Untuk mengetahui epektif suatu metode dalam kegiatan pembelajaran perlu diadakan analisis data. Pada penelitian ini menggunakan teknik analisa deskriptif kualitatif, yaitu suatu metode penelitian yang bersifat menggambarkan kenyataan atau fakta sesuai dengan data yang diperoleh dengan tujuan untuk mengetahui prestasi belajar yang dicapai siswa juga untuk memperoleh respon siswa terhadap kegiatan pembelajaran serta aktivitas siswa selama proses pembelajaran.

Untuk menganalisis tingkat keberhasilan atau persentase keberhasilan siswa setelah proses belajar mengajar setiap putarannya dilakukan dengan cara memberikan evaluasi berupa tes praktek pada setiap akhir putaran,

Analisa ini dihitung dengan menggunakan statistik sederhana yaitu Untuk menilai tes praktek Peneliti melakukan penjumlahan nilai yang diperoleh siswa yang selanjutnya dibagi dengan jumlah siswa yang ada di kelas tersebut sehingga diperlukan rata-rata tes praktek dapat dirumuskan
$\bar{X}=\frac{\sum X}{\sum N}$

Dengan

$\bar{X}=$ Nilai rata-rata

$\sum X=$ Jumlah semua nilai

siswa

$$
\sum N=\text { Jumlah siswa }
$$

Untuk ketuntasan belajar

Ada dua kategori ketuntasan belajar yaitu secara perorangan dan secara klasikal. Berdasarkan petunjuk pelaksanaan belajar mengajar kurikulum 2004 (Depdikbud,2004) yaitu siswa telah tuntas belajar bila di kelas tersebut mendapat $85 \%$ yang telah mencapai daya serap.

Untuk menghitung persentase ketuntasan belajar digunakan rumus sebagai berikut:

$$
P=\frac{\sum \text { Siswayangtuntasbelajar }}{\sum \text { siswa }} \times 100 \%
$$

\section{HASIL PENELITIAN DAN PEMBAHASAN \\ Siklus I}

Pelaksanaan kegiatan belajar mengajar untuk siklus I dilaksanakan pada hari Selasa 30 Juli 2019 di kelas VI dengan jumlah siswa 28 siswa. Adapun proses belajar mengajar mengacu pada rencana pelajaran yang telah dipersiapkan.

Pada akhir proses belajar mengajar siswa diberi tes formatif I dengan tujuan untuk mengetahui keberhasilan siswa dalam proses belajar mengajar yang telah dilakukan. Adapun $\backslash$ hasil penelitian pada siklus I dapat dijelaskan bahwa; dengan menerapkan tekhnik operan give and go pada siklus I diperoleh nilai ratarata hasil belajar siswa adalah 68,42 dari 28 siswa, jumlah siswa yang tuntas belajar 12 orang atau sebesar $42 \%$ ketuntasan belajar, kemudian siswa yang tidak tuntas belajar sebanyak 16 orang atau sebesar 58 $\%$.Hasil tersebut menunjukkan bahwa pada siklus pertama secara klasikal siswa yang belum tuntas belajar atau memperoleh nilai $\geq 70$ sebesar $42 \%$ lebih kecil dari persentase ketuntasan yang dikehendaki yaitu sebesar $\geq 80 \%$. Hal ini disebabkan karena siswa masih merasa baru dan belum 
begitu paham dengan tekhnik operan give and go dalam pembelajaran olah raga.

\section{Siklus II}

Pelaksanaan kegiatan belajar mengajar untuk siklus II dilaksanakan pada hari Selasa tanggal 13 Agustus 2019 di kelas VI dengan jumlah siswa 28 siswa. Adapun proses belajar mengajar mengacu pada rencana pelajaran dengan memperhatikan revisi pada siklus I, Pada akhir proses belajar mengajar siswa diberi tes formatif II dengan tujuan untuk mengetahui tingkat keberhasilan siswa dalam proses belajar mengajar yang dilakukan. Instrument yang digunakan adalah tes. Adapun hasil penelitian pada siklus II nilai rata-rata tes tulis sebesar 82,89 dari 28 siswa yang telah tuntas belajar sebanyak 26 siswa dengan persentase sebesar $93 \%$ dan 2 siswa belum tuntas belajar atau sebesar 7\%. Ketuntasan belajar klasikal tercapai sebesar 93\%. Hasil pada siklus II ini mengalami peningkatan yang signifikan dari siklus I. Adanya peningkatan hasil belajar pada siklus II ini dipengaruhi oleh adanya peningkatan kemampuan guru dalam menerapkan pembelajaran operan dengan tekhnik operan give and go sehingga siswa menjadi lebih terbiasa dengan pembelajaran seperti ini sehingga siswa lebih mudah dalam memahami materi yang telah diberikan, sehingga penelitian ini dihentikan sampai pada siklus II.

\section{Pembahasan}

Dari tabel di atas dapat dijelaskan bahwa dengan menerapkan tekhnik operan give and go pada siklus I diperoleh nilai rata-rata hasil belajar siswa adalah 68,42 dari 28 siswa, jumlah siswa yang tuntas belajar 12 orang atau sebesar $42 \%$ ketuntasan belajar, kemudian siswa yang tidak tuntas belajar sebanyak 16 orang atau sebesar $58 \%$.Hasil tersebut menunjukkan bahwa pada siklus pertama secara klasikal siswa yang belum tuntas belajar atau memperoleh nilai $\geq 70$ sebesar $42 \%$ lebih kecil dari persentase ketuntasan yang dikehendaki yaitu sebesar $\geq 80 \%$. Hal ini disebabkan karena siswa masih merasa baru dan belum begitu paham dengan tekhnik operan give and go dalam pemainan sepak bola.

Berdasarkan tabel di atas diperoleh nilai rata-rata tes tulis sebesar 82,89 dari 28 siswa yang telah tuntas belajar sebanyak 26 siswa dengan persentase sebesar $93 \%$ dan 2 siswa belum tuntas belajar atau sebesar 7\%. Ketuntasan belajar klasikal tercapai sebesar 93\%. Hasil pada siklus II ini mengalami peningkatan yang signifikan dari siklus I. Adanya peningkatan hasil belajar pada siklus II ini dipengaruhi oleh adanya peningkatan kemampuan guru dalam menerapkan pembelajaran operan dengan tekhnik operan give and go sehingga siswa menjadi lebih terbiasa dengan pembelajaran seperti ini sehingga siswa lebih mudah dalam memahami materi yang telah diberikan, sehingga penelitian ini dihentikan sampai pada siklus II.

Jika melihat hasil belajar siswa dari kedua siklus tersebut diatas terjadi peningkatan hasil belajar yang signifikan dari siklus I menuju siklus II , nilai rata rata diperoleh pada siklus I sebesar 68,42 kemudian meningkat pada siklus II nilai rata - rata diperoleh sebesar 82,89 terjadi peningkatan sebesar 14,47 poin, kemudian jumlah siswa yang tuntas pada siklus I sebanyak 12 siswa dengan persentase sebesar $42 \%$ dan pada siklus II jumlah siswa yang tuntas sebanyak 26 siswa dengan persentase sebesar $93 \%$ terjadi peningkatan sebesar 51 poin, begitu juga dengan ketuntasan klasikal yang dipatok sebesar $\geq 80 \%$ juga sudah tercapai maka dengan demikian semua indikator yang dipersyaratkan sudah tercapai, maka penelitian ini dihentikan sampai pada siklus II.

Dengan demikian dapat ditarik kesimpulan bahwa dengan menggunakan tekhnik operan dalam permainan sepak bola dengan tekhnik give and go dapat meningkatkan hasil belajar siswa kelas VI di SDN Esot Kecamatan Pringgarata Tahun pelajaran 2019 / 2020.

\section{PENUTUP}

Dari hasil kegiatan pembelajaran yang telah dilakukan selama 
dua siklus dan berdasarkan seluruh pembahasan serta analisis yang telah dilakukan dapat disimpulkan, bahwa terjadi peningkatan hasil belajar yang signifikan dari siklus I menuju siklus II dimana nilai rata - rata pada siklus I diperoleh sebesar 68,42 kemudian meningkat pada siklus II nilai rata - rata diperoleh sebesar 82,89 terjadi peningkatan sebesar 14,47 poin, kemudian jumlah siswa yang tuntas pada siklus I sebanyak 12 siswa dengan persentase sebesar $42 \%$ dan pada siklus II jumlah siswa yang tuntas sebanyak 26 siswa dengan persentase sebesar $93 \%$ terjadi peningkatan sebesar 51 poin, begitu juga dengan ketuntasan klasikal yang dipatok sebesar $\geq 80 \%$ juga sudah tercapai maka dengan demikian semua indikator yang dipersyaratkan sudah tercapai, maka penelitian ini dihentikan sampai pada siklus II.

Dengan demikian dapat ditarik kesimpulan bahwa dengan menggunakan tekhnik operan dalam permainan sepak bola dengan tekhnik give and go dapat meningkatkan hasil belajar siswa kelas VI di SDN Esot Kecamatan Pringgarata Tahun pelajaran 2019 / 2020.

\section{DAFTAR PUSTAKA}

Arikunto, Suharsimi , 2012. Prosedur Penelitian Suatu Pendekatan Praktik. Jakarta PT. Rineksa Cipta

Bachrie, Eddy, dkk. 2012. Buku Kerja Pelatih Sepakbola Remaja. Bandung; Binacipta

Betty, C. Eric. 2017. Latihan Sepakbola Metode Baru Pertahanan. Bandung; Pioner Jaya

Coever, Weil.2012; Sepakbola Pembinaan Pemain Ideal. Jakarta; PT Gramedia.

Engkos S.R.2014. Penjaskes. Jakarta; Erlangga

Remmy, Muchtar. 2012 . Olah Raga Pilihan Sepak Bola, Jakarta; Depdikbud Dirjen Dikti

Roji. 2016. Penjaskes 3, Jakarta; Intan Parawara
Sajono, 2016. Pembinaan dan Kondisi fisik, Jakarta: Depdikbud Dirjen Dikti

Slamet, S.R. 2014.Penjaskes 3. Jakarta; Tiga Serangkai

Sneyer, J. 2015. Sepakbola Latihan dan Strategi, Jakarta; PT. Rosda Karya

Suharno. 2016, Ilmu Kepelatihan Olah Raga Yogyakarta; IKIP Yogyakarta.

Syafi'I, Imam, 2012, Sepakbola Dasar. Surabaya; UM Press IKIP Surabaya

Syarifuddin, Aib. 2015, Penjaskes 1,2,3, Jakarta; PT. Gramedia Widiasmara Indonesia 